\title{
Silicon dioxide and Bacillus subtilis applied in controlling wheat diseases
}

\author{
Fábio Júnior Telaxka ${ }^{1} \oplus$, Cacilda Márcia Duarte Rios Faria ${ }^{1} \oplus$, Aline José Maia ${ }^{1}$,

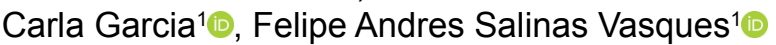
1 Universidade Estadual do Centro Oeste, Departamento de Agronomia, Guarapuava-PR, Brasil. E-mail: fabio1910@live.com; criosfaria@hotmail.com; alymaia2005@gmail.com; carlagarciaagro@gmail.com; felipesalinasvasques@gmail.com

ABSTRACT: Wheat is a crop that has high production; however, one of the limitations in planting is the presence of diseases, with the gibberella (Gibberella zeae) and yellow spot (Drechslera tritici-repentis) among them. Thus, the objective of this study was to evaluate the potential of fungicides based on strobilurins, silicon dioxide $\left(\mathrm{SiO}_{2}\right)$ and $\mathrm{B}$. subtilis in controlling these diseases in wheat. The used treatments for all the experiments were: $\mathrm{T}_{1}-\mathrm{SiO}_{2} ; \mathrm{T} 2-\mathrm{B}$. subtilis; $\mathrm{T} 3-\mathrm{SiO}_{2}+B$. subtilis; $\mathrm{T} 4-$ trifloxystrobin + prothioconazole/trifloxystrobin + tebuconazole; T5-Control. For the field experiment, conducted in two locations, evaluations of the incidence of gibberella and yellow spot severity, crop agronomic characteristics and polyphenoloxidase (PPO) and phenylalanine ammonia-lyase (PAL) activities were carried out. According to the obtained results, the fungicides based on strobilurins and $\mathrm{SiO}_{2}$ reduced the severity of the yellow spot, increasing, on average, $10 \mathrm{~g}$ the weight of a thousand grains (WTG) and the activity of the $\mathrm{PPO}$ and PAL enzymes in both municipalities. Hence, $\mathrm{SiO}_{2}$ possibly activated the defense mechanisms of these plants disease severity.

Key words: biological control; mineral nutrition; resistance induction

\section{Avaliação de dióxido de silício e Bacillus subtilis no controle de doenças do trigo}

RESUMO: A cultura do trigo apresenta elevada produção, no entanto, uma das limitações no plantio é a presença de doenças, dentre elas podemos citar a giberela (Gibberella zeae) e mancha-amarela (Drechslera tritici-repentis). Dessa forma o objetivo do trabalho foi avaliar o potencial de fungicidas a base de estrobilurinas, do dióxido de silício $\left(\mathrm{SiO}_{2}\right)$ e de $B$. subtilis no controle dessas doenças no trigo. Os tratamentos utilizados para todos os experimentos foram: $\mathrm{T}_{1}-\mathrm{SiO}_{2} ; \mathrm{T} 2-\mathrm{B}$. subtilis; $\mathrm{T}_{3}-\mathrm{SiO}_{2}+$ B. subtilis; T4- trifloxistrobina + protioconazol/trifloxistrobina + tebuconazol; T5-Testemunha. Para o experimento de campo, realizado em duas localidades, foram realizadas avaliações da incidência da giberela e severidade mancha amarela, das características agronômicas da cultura e a atividade da polifenoloxidase (PPO) e fenilalanina amônia-liase (PAL). De acordo com os resultados obtidos o tratamento químico a base de estrobilurinas e $0 \mathrm{SiO}_{2}$ reduziu em a severidade da mancha amarela, aumentou, em média $10 \mathrm{~g}$ a massa de mil grão (PMS) e elevou a atividade das enzimas PPO e PAL em ambos os municípios. Assim $0 \mathrm{SiO}_{2}$ possivelmente ativou os mecanismos de defesa dessas plantas, e severidade das doenças.

Palavras-chave: controle biológico; nutrição mineral; indução de resistência 


\section{Introduction}

The global production of wheat (Triticum aestivum L.) in the 2017/2018 harvest was of approximately 760 million tons. In Brazil, the states with the highest production were Rio Grande Sul, Santa Catarina and Paraná, with yield in the $2017 / 2018$ crop of $2,746,2,696$ and $2624 \mathrm{~kg} \mathrm{ha}^{-1}$, respectively (Conab, 2018).

Despite the high global production, the wheat crop has some limitations. Among the most noticeable ones are the occurrence of diseases, such as gibberella (Gibberella zeae Schw) and yellow spot (Drechslera tritici- repentis [Died]) (Dorneles et al., 2019).

Gibberella can reduce wheat yield from $20 \%$ to $50 \%$, in addition to the hectoliter ( $\mathrm{PH})$ weight reduction as well. However, one of the main problems related to gibberella is the contamination of the grains by mycotoxins, toxic metabolites produced by the fungus. The main mycotoxin is deoxyvalenol (DON), considered carcinogenic to humans (Prado, 2017). Yellow spot is a leaf disease that reduces the active photosynthetic area of plants by the formation of necrosis and/or extensive chlorosis. Yield reduction can reach up to $48 \%$ (Moffat et al., 2014).

The main form of control of these diseases is chemical. In order not to have many harms for the producer, consumer and the environment, responsible use is necessary. Thus, mixtures of active principles and combinations with other control methods such as cultural and biological are used (Amorim et al., 2011).

Among the chemicals that protect the plant against pathogen attack are strobilurin-based systemic fungicides, which in addition to the fungitoxic action, can have positive physiological effects on plants (Phytus Institute, 2015). Another way to reduce the disease severity is to supply plants with silicon (Si). This element can act directly on the pathogen, reducing mycelial growth and spore germination (Elsherbiny \& Taher, 2018) and can act on plant defense mechanisms (Bakhat et al., 2018). Biological control has also been successfully applied in controlling plant diseases by using antagonistic agents (Fira et al., 2018).

Thereby, the aim of this study was to evaluate the effect of foliar applications of silicon ( $\mathrm{Si}$ ), B. subtilis and strobilurins fungicides on the control of gibberella and yellow spot, as well as to quantify the activity of the enzymes related to plant defense, polyphenoloxidase (PPO) and phenylalanine ammonia-lyase (PAL).

\section{Materials and Methods}

In the trials, the TBIO Toruk wheat cultivar was used, sown under field conditions in the 2016/2017 agricultural year, in two locations, both having climate of the mesothermal $\mathrm{Cfb}$ type (humid subtropical climate), with fresh summers and no defined dry season, according to the Köppen classification. Two distinct experiments were conducted, with the first within a rural property in Virmond-PR, with $25^{\circ} 37^{\prime} \mathrm{S}$ latitude, $52^{\circ} 20^{\prime} \mathrm{W}$ longitude and altitude of 713 meters. At this site, the wheat sowing took place on 06/06/2016. The second experiment was conducted within the experimental area from the Department of Agronomy of the State University of the Central West - UNICENTRO, located in Guarapuava-PR, with $25^{\circ} 41^{\prime} \mathrm{S}$ latitude, $51^{\circ} 38^{\prime} \mathrm{W}$ longitude and approximately 1120 meters of altitude, having the sowing been held on 07/20/2016.

In Virmond municipality, the sowing density was 315 viable seeds $\mathrm{m}^{-2}$, equivalent to approximately $105 \mathrm{~kg}$ seeds ha-1, with row spacing of $0.17 \mathrm{~m} .250 \mathrm{~kg} \mathrm{ha}^{-1}$ of NPK from the 10-30-20 commercial formula were used, according to soil analysis and crop requirement, distributed in the sowing furrow. Nitrogen fertilization was also performed in the tillering stage, with 130 $\mathrm{kg} \mathrm{ha}^{-1}$ of urea. In Guarapuava, the density was approximately of 360 viable seeds $\mathrm{m}^{2}$, using $120 \mathrm{~kg}$ of seeds ha-1, with a row spacing of $0.17 \mathrm{~m} .300 \mathrm{~kg} \mathrm{ha}^{-1}$ of NPK from the commercial formula 10-30-20 were used, just as previous experiment. Nitrogen fertilization was also similar to the experiment conducted in Virmond.

The experimental design was in randomized blocks (RBD), with five treatments and four replicates. Experimental units consisted of plots of 10 sowing lines $3 \mathrm{~m}$ long and $1.7 \mathrm{~m}$ wide. For harvesting purposes, $2 \mathrm{~m}$ of length by $1.10 \mathrm{~m}$ of width from each plot were considered as useful areas.

Used treatments in both experiments were: T1 - Silicon dioxide (98\% $\mathrm{SiO}_{2}$ Agrisil $^{\circ}, 0.3 \mathrm{~kg} \mathrm{ha}^{-1}$ ); $\mathrm{T} 2$ - Bacillus subtilis (Serenade ${ }^{\circ}$ QST 713 strain, at the 3 L p.c. ha ${ }^{-1}$ dose); $\mathrm{T}^{-}-\mathrm{SiO}_{2}+$ $B$. subtilis; T4 - Mixture of trifloxystrobin + protioconazole and trifloxystronin + tebuconazole (Fox ${ }^{\bullet}$ and Nativo ${ }^{\circ}$ at doses of 0.5 L p.c. ha ${ }^{-1}$ and 0.7 L p.c. ha ${ }^{-1}$, respectively); T5 - control (no treatment applied). Treatments were sprayed with a manual backpack sprayer in the stages of tillering, elongation, booting and flowering of the crop.

In order to obtain the data on gibberella incidence and yellow spot severity, six weekly evaluations were performed from the crop tillering.

Gibberella incidence on the wheat ears was determined by counting 100 ears from the center of each plot. To determine the incidence percentage, the adapted equation proposed by Deuner et al. (2015): INC (\%) = [NIL/ TNLE] * 100, where, INC - Incidence, NIL - Number of injured leaves/ears, TNLE Total number of ears/leaves evaluated. The gibberella severity was determined by counting the number of spikelets infected by ear, totaling 30 ears from the center of each plot. These data were expressed as a percentage obtained from the mean number of gibberella-ridden spikelets as a function of the mean number of spikelets per ear, considering $100 \%$ of the total spikelets from the ears (Deuner et al., 2015). With these data on incidence and severity of gibberella, the disease index was determined by the formula: [(incidence $x$ severity) / 100].

Severity of the yellow spot was determined by using the adapted diagrammatic scale of wheat septoriosis proposed by Azevedo (1997).

Evaluated agronomic characteristics were: weight of a thousand grain (g) (WTG), yield $\left(\mathrm{kg} \mathrm{ha}^{-1}\right)$ and hectoliter weight 
(HW), all evaluated by using $250 \mathrm{~mL}$ of sample from each heavy plot (Melero et al., 2013).

For the biochemical analyzes, leaves of plants from the center of each plot (approximately $1 \mathrm{~g}$ ) were collected in two moments. The first collection was 24 hours before the second application, performed at the crop elongation stage, in Virmond (First VC) and Guarapuava (First GC). The second collection was 24 hours after the fourth application of the treatments, at the crop flowering stage in Virmond (Second VC) and Guarapuava (Second GC).

Leaves were stored in aluminum foil, refrigerated on ice and then stored in a freezer at $-20{ }^{\circ} \mathrm{C}$ until the extracts preparation for biochemical analysis. They were then weighed, macerated in a mortar with liquid nitrogen, and mechanically homogenized in $4 \mathrm{~mL}$ of $50 \mathrm{mM}$ potassium phosphate buffer (pH 7) containing $0.1 \mathrm{mM}$ EDTA and polyvinylpyrrolidone (PVP). This solution was transferred to a microtube and centrifuged at $15000 \mathrm{~g}$ for $40 \mathrm{~min}$ at $4{ }^{\circ} \mathrm{C}$.

Enzymatic extract obtained from the centrifugation supernatant was stored in a freezer at $-20^{\circ} \mathrm{C}$ until biochemical analyzes were held. Protein content was determined by the method of Bradford (1976). Polyphenoloxidase activity (PPO E.C. 1.10.3.1) was determined by a catechol-using spectrophotometer, according to the methodology proposed by Duangmal \& Apenten (1999), and phenylalanine ammonialyase (FAL EC 4.3.1.5) was quantified by trans-cinnamic acid colorimetry, released by the phenylalanine substrate, according to the adapted method described by Umesha (2006).

The results obtained in all tests were subjected to analysis of variance by the $\mathrm{F}$ test and, when significant, they were also subjected to the mean comparison analysis by the Tukey and Scott-Knott tests at the 5\% significance level. Analyzes were performed aided by the SISVAR software (Ferreira, 2011).

\section{Results and Discussion}

Regarding the gibberella, in Virmond municipality, the strobilurin-based chemical treatment showed lower disease index when compared to the control, although it did not had statistical difference with $\mathrm{SiO}_{2}, B$. subtilis, $\mathrm{SiO}_{2}+B$. subtilis. These treatments reduced by $70 \%, 43.3 \%$ and $50 \%$ in comparison to the control, respectively. In Guarapuava, there was no statistical difference among treatments (Table 1).

On the other hand, for leaf spot (D. tritici-repentis), the lowest severity was obtained when using strobilurin-based chemical treatment followed by $\mathrm{SiO}_{2}+B$. subtilis, $\mathrm{SiO}_{2}$ and $B$. subtilis which reduced by $69.6 \%, 66.4 \%, 72.2 \%$ and $93.3 \%$ the disease severity in relation to the control in Virmont municipality (Figure 1A). In Guarapuava, the lowest severity was obtained in the $\mathrm{SiO}_{2}$ treatment, followed by $B$. subtilis, which did not differ from the chemical treatment. These treatments reduced the leaf spot severity by $83.5 \%, 82.1 \%$ and $85.8 \%$, respectively. $\mathrm{SiO}_{2}+B$. subtilis treatment showed a reduction in leaf spot severity in relation to the control; however, it was lower than the strobilurin-based chemical
Table 1. Gibberella (Gibberella zeae Schw) index in wheat plants treated with silicon dioxide $\left(\mathrm{SiO}_{2}\right) ; B$. subtilis; $\mathrm{SiO} 2+$ B. subtilis; trifloxystrobin + protioconazole/trifloxystronin + tebuconazole (chemical treatment) and Control (no application) in Virmont-PR and Guarapuava-PR.

\begin{tabular}{lcc}
\hline \multicolumn{1}{c}{ Treatments } & $\begin{array}{c}\text { Gibberella index } \\
\text { (Virmond) }\end{array}$ & $\begin{array}{c}\text { Gibberella index } \\
\text { (Guarapuava) }\end{array}$ \\
\hline $\mathrm{SiO}_{2}$ & $0.17 \mathrm{ab}$ & $1.05 \mathrm{a}$ \\
B. subtilis & $0.17 \mathrm{ab}$ & $0.92 \mathrm{a}$ \\
$\mathrm{SiO}_{2}+$ B. subtilis & $0.15 \mathrm{ab}$ & $0.84 \mathrm{a}$ \\
Chemical & $0.09 \mathrm{a}$ & $0.81 \mathrm{a}$ \\
Control & $0.3 \mathrm{~b}$ & $1.6 \mathrm{a}$ \\
$\mathrm{CV}(\%)$ & 44.9 & 45 \\
\hline
\end{tabular}

Same letters did not differ from each other by the Tukey test $(p \geq 0.05)$.
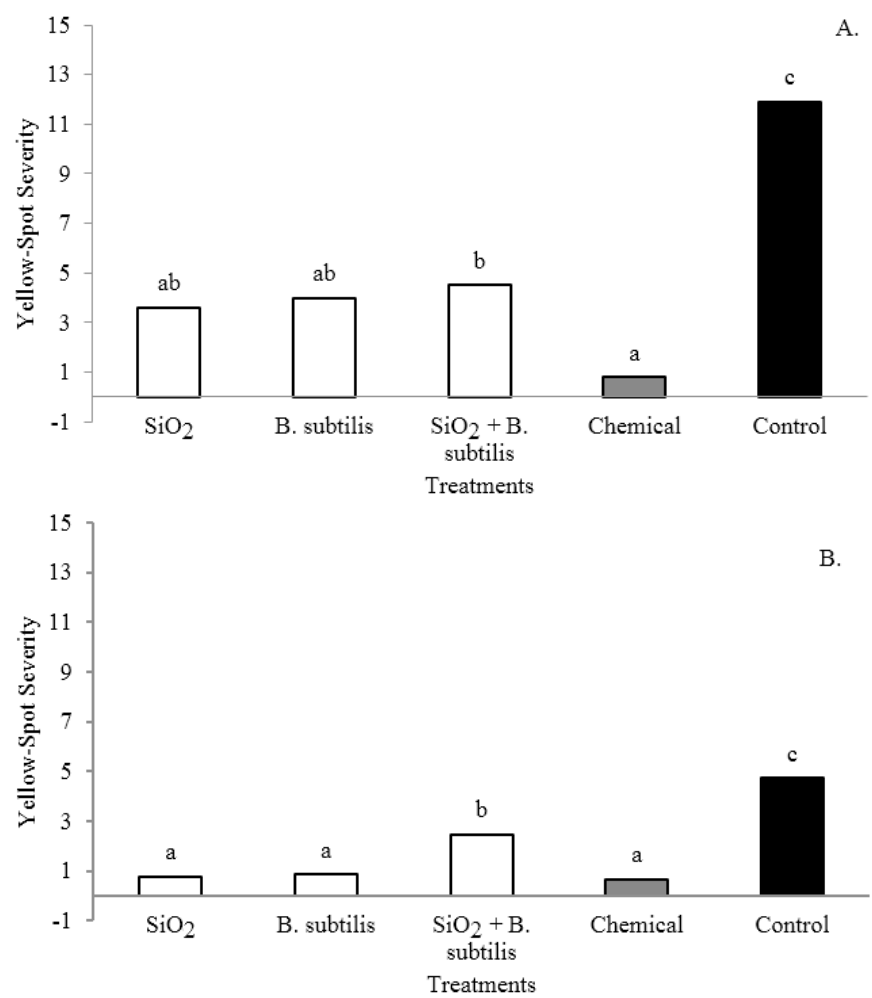

Figure 1. Severity of yellow spot (Drechslera tritici-repentis) in wheat plants grown in Virmond-PR (A) and Guarapuava$\mathrm{PR}(\mathrm{B})$ and treated with silicon dioxide $\left(\mathrm{SiO}_{2}\right) ; \mathrm{B}$. subtilis; $\mathrm{SiO}_{2}$ + B. subtilis; trifloxystrobin + protioconazole/trifloxystronin + tebuconazole (chemical treatment) and Control (no application). Same letters did not differ by Scott-Knott test ( $p$ $\geq 0.05$ ).

treatment (Figure 1B). The difference in disease occurrence between the two municipalities was due to environmental issues.

Strobilurin-based chemical control showed the best control of both diseases in wheat crop, regardless of the location. These results are possibly related to the mode of action of strobilurins, by inhibiting mitochondrial respiration. That way, there is a blockage in the electron transference between $b$ cytochrome and c1cytochrome at $Q$ site, interfering with the production of ATP and energy of the pathogen (Kanungo \& Joshi, 2014; Matos et al., 2016) 
For both diseases in wheat plants, the treatment with $\mathrm{SiO} 2$ showed similar behavior to the chemical strubilurinesbased treatment. One of the evidences is the ability of $\mathrm{Si}$ in being deposited on the cell surface, at the subcuticular layer, in the cell wall and intracellular spaces, forming physical barriers that hinder the fungal pathogen entrance. Another possible assumption is that this element is related to the biosynthesis of phenolic compounds deposited in the cell wall. These substances have antimicrobial capacity that act directly on pathogens, preventing their development (Shalaby \& Benjamin, 2015; Bakhat et al., 2018).

Wheat plants treated with $B$. subtilis also showed reduction in leaf spot and gibberella index, possibly due to the antagonistic action of $B$. subtilis exerted on the pathogens. This non-pathogenic microorganism has the ability to produce compounds with antimicrobial action called lipopeptides, which leads to destabilization of the pathogen cell membrane, causing intracellular content release. However, this compound may have heat sensitivity, thus not triggering this antifungal effect (Fira et al., 2018), and the $B$. subtilis strains may take a longer time to colonize (Comby et al., 2017), so, the phytopathogen control is not satisfactory.

Association between $\mathrm{SiO}_{2}+B$. subtilis reduced the incidence of gibberella and the severity of yellow spot; however, it was still lower than $\mathrm{SiO}_{2}$ and $B$. subtilis treatments separately. This fact is possibly due to the ability of silicon in being deposited on the bacterial plasma membrane, causing changes in its cell morphology, cell wall distortion and deformation, antimicrobial effect and thus hindering bacilli biological control (Baig et al., 2018).

In Virmond municipality, severity of yellow spot was higher while it was lower in Guarapuava, probably due to environmental conditions, considering that the average precipitation there between July and December 2016 was $17 \mathrm{~nm}$, with maximum and minimum temperature of 22 oC and $10 \stackrel{\circ}{ } \mathrm{C}$, respectively; while in Virmond, it was $15 \mathrm{mn}$, with maximum and minimum temperatures of $24{ }^{\circ} \mathrm{C}$ and $10{ }^{\circ} \mathrm{C}$ (Simepar, 2016). These environmental conditions possibly explain the low indexes of gibberella and yellow spot in Guarapuava municipality, since for their development prolonged periods of rain (above 72 hours) and average temperature of 15 to $20^{\circ} \mathrm{C}$ are necessary (Reis et al., 2001).
Another fact that can be pointed out is that the causal agent of this disease, $D$. tritici- repentis, is necrotrophic, which favors its survival in the crop remains, especially in regions that practice no-tillage (Prestes et al., 2002). However, at the experiment site, in Guarapuava, crop rotation is performed, which reduces the inoculum pressure and consequently the disease severity, while in Virmond the site it is a commercial property.

In relation to the agronomic characteristics, we observed that the strobilurin-based chemical treatment had higher weight of thousand grains of wheat, followed by $\mathrm{SiO}_{2}$ treatments; $B$. subtylis and $\mathrm{SiO}_{2}+B$. subtilis, with all of these treatments higher to control and being within the standard established in both locations (Table 2). WTG variation was from 32.2 to $39.6 \mathrm{~g}$, which can be explained by the crop management (Gutkoski et al., 2008).

Concerning the yield, strobilurin-based chemical treatment increased by $17 \%$ when compared to control in Virmond municipality. In Guarapuava, there was no statistical difference between the treatments. Hectoliter weight of wheat crop, when chemically treated, increased by approximately $10 \%$ in relation to the control in both municipalities (Table 2). In Guarapuava, plants that received the treatments $\mathrm{SiO}_{2^{\prime}}$ B. subtilis and $\mathrm{SiO}_{2}+B$. subtilis also showed an increase of approximately $5 \%$ when compared to the control (Table 2 ).

In general, the weight of thousand grains (WTG), yield $(\mathrm{Y})$ and hectoliter weight (HW) were higher with strobilurinbased chemical treatment. This active principle acts in reducing ethylene production, which slows leaf senescence, and in turn increase the period the plant remains with active photosynthesis, also called the 'green effect' (Fagan et al., 2010), which may explain the increase in yield and the hectoliter weight of the crop. However, treatments with $\mathrm{SiO}_{2}$, B. subtilis and $\mathrm{Si}+B$. subtilis also increased the weight of thousand grains and hectoliter weight. These results are probably associated with the high concentration of chlorophyll provided by $\mathrm{Si}$ and the increased synthesis of the gibberillin plant hormone (GA) caused by Bacillus, thus leading to greater plant development (Maillard et al., 2018).

In the biochemical analysis, the verified results for PPO and the plants treated with $\mathrm{SiO}_{2}$, in Virmond, increased the specific activity of this enzyme. In the first collection, $\mathrm{SiO}_{2}$ had

Table 2. Weight of thousand grains (WTG) $(\mathrm{g})$, yield $(\mathrm{Y})\left(\mathrm{kg} \mathrm{ha}^{-1}\right)$ and hectoliter weight (HW) of wheat crop obtained in the field for the municipalities of Virmond-PR and Guarapuava-PR 2016.

\begin{tabular}{|c|c|c|c|c|c|c|c|}
\hline \multirow{2}{*}{ Variables } & \multicolumn{5}{|c|}{ Treatments } & \multirow{2}{*}{$\begin{array}{l}\text { Overall } \\
\text { mean }\end{array}$} & \multirow{2}{*}{$\begin{array}{l}\text { CV } \\
(\%)\end{array}$} \\
\hline & T1 & T2 & T3 & T4 & T5 & & \\
\hline & \multicolumn{7}{|c|}{ Virmond } \\
\hline WTG & $35.5 \mathrm{~b}$ & $35.1 \mathrm{~b}$ & $34.3 \mathrm{~b}$ & $37.0 \mathrm{c}$ & $32.22 \mathrm{a}$ & 34.82 & 2.01 \\
\hline$Y$ & $3347.58 a$ & $3406.2 \mathrm{a}$ & 3306.57 a & $3743.69 \mathrm{~b}$ & 3200.94 a & 3401.0 & 4.28 \\
\hline \multirow[t]{2}{*}{ HW } & $71.12 \mathrm{a}$ & $71.25 \mathrm{a}$ & $70.65 \mathrm{a}$ & $75.39 \mathrm{~b}$ & $68.82 \mathrm{a}$ & 71.45 & 1.86 \\
\hline & \multicolumn{7}{|c|}{ Guarapuava } \\
\hline PMS & $38.85 b$ & $38.6 \mathrm{~b}$ & $37.9 \mathrm{~b}$ & $39.6 b$ & $34.92 \mathrm{a}$ & 37.97 & 2.79 \\
\hline$Y$ & 4168.57 a & $4111.67 \mathrm{a}$ & 3959.55 a & $4644.8 \mathrm{a}$ & 3837.65 a & 4144.45 & 9.68 \\
\hline HW & $73.56 \mathrm{~b}$ & $72.96 \mathrm{~b}$ & $72.24 \mathrm{~b}$ & $77.4 \mathrm{c}$ & $69.52 \mathrm{a}$ & 73.14 & 2.53 \\
\hline
\end{tabular}

Same letters on the row did not differ from each other by the Scott-Knott test $(p \geq 0.05)$. 
higher enzyme activity, with $50 \%$ increase compared to the other treatments. In the second collection the treatments with $\mathrm{SiO}_{2}, \mathrm{SiO}_{2}+B$. subtilis and chemical showed higher enzyme activity in relation to the other treatments, also not having statistical differences among themselves (Figure $2 \mathrm{~A}$ and $\mathrm{C}$ ).

For Guarapuava, $\mathrm{SiO}_{2}+B$. subtilis treatment showed higher enzymatic activity, with an increase of $400 \%$ in the first GC and $600 \%$ in the second GC (Figure $2 \mathrm{~B}$ and D).

The high PPO activity may contribute to the biochemical defenses of wheat against pathogens, because phenolic compounds are usually found in the plants and, with the activation of this enzyme, these compounds become highly toxic. This toxicity occurs by the PPO oxidation, which originates the quinones. These can inactivate the pectolytic enzymes produced by the pathogens, preventing their development in the plant (Shalaby \& Benjamin, 2015).

In addition to PPO being involved in the synthesis of these secondary plant antimicrobial proteins/enzymes, it also plays a significant role in lignin biosynthesis. This enzyme acts as a complement to plant lignification, since quinones spontaneously bind to the cell wall, forming a phenolic barrier that helps control fungal diseases (Song et al., 2016).

Regarding PAL, we also observed an increase of its activity in plants treated with $\mathrm{SiO}_{2}$. In relation to the control, in Virmond, this enzyme presented an increase of $83 \%$ in the first VC, statistically differing from the other treatments. In the second collection, this treatment was the same as the
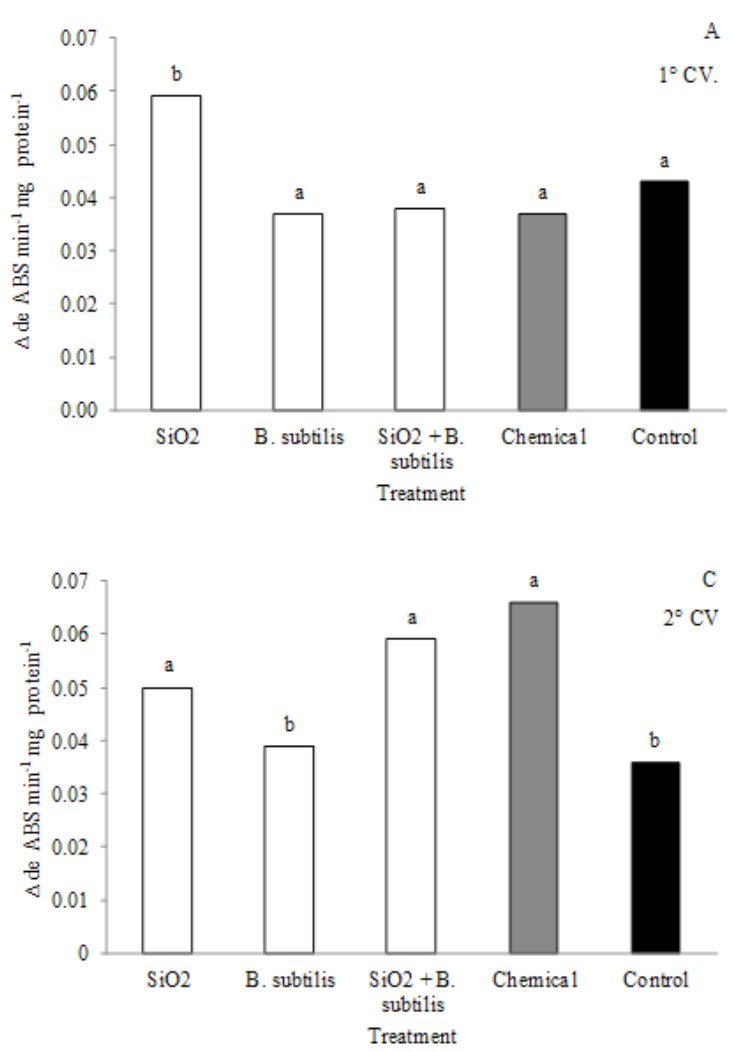

chemical treatment (Figure $3 \mathrm{~A}$ and $\mathrm{C}$ ). In Guarapuava, in the first collection, $\mathrm{SiO}_{2}$ and $B$. subtilis treatments showed higher enzymatic activity, while in the second collection the treatments that stood out were silicon and chemical (Figure $3 \mathrm{~B}$ and $\mathrm{D})$.

Increasing activity of $\mathrm{PAL}$, provided by $\mathrm{SiO}_{2}$, is important for the deposition of lignin in the cell wall and for assisting in the cells resistance against pathogens. This enzyme is from the phenylpropanoid pathway that absorbs approximately $30 \%$ to $40 \%$ of organic carbon and integrates them as part of lignin polymers. PAL starts this route and is responsible for the deamination of the amino acid L-phenylalanine that results in the transformation in trans-cinnamic acid and ammonia. Subsequently, there is the formation of monolignols used in lignin deposition (Zhang \& Chang-Jun, 2015).

It is distinctive that the combination treatment of $\mathrm{SiO}_{2}+B$. subtilis increased the activity of PAL and PPO; however, it was not sufficient to reduce the severity of yellow spot in wheat plants. This may be related to the absence of resistance signal transduction that should be transmitted in the plant, the sensitivity of the pathogen by quinones and/or the deposition of lignin (Oliveira et al., 2016).

Therefore, the treatment with $\mathrm{SiO}_{2}$ increased the activity of the enzymes PPO and PAL, which consequently contributed to the control of gibberella (G. zeae) and yellow spot (D. triticirepentis). Hence, it can be emphasized that this treatment activated the defense mechanisms of wheat plants that
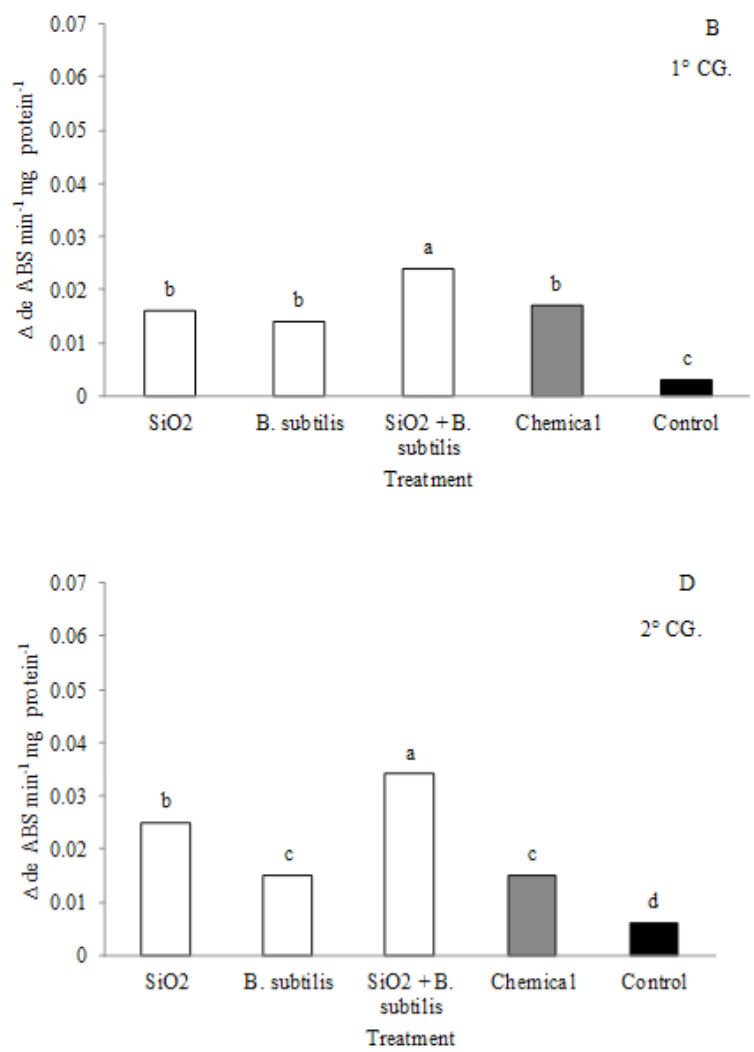

Figure 2. Specific activity of polyphenoloxidase enzyme (PPO) in wheat leaves treated with silicon dioxide (SiO2); $B$. subtilis; SiO2 + B. subtilis; trifloxystrobin + protioconazole/trifloxystronin + tebuconazole (chemical treatment) and Control (no application) on the first and second collections in Virmond-PR (first VC [A] and second VC [C]) and Guarapuava-PR (first GC (B) and second GC (D) Means followed by the same letter on the row do not differ from each other by the Scott-Knott test ( $p \geq 0.05)$. 

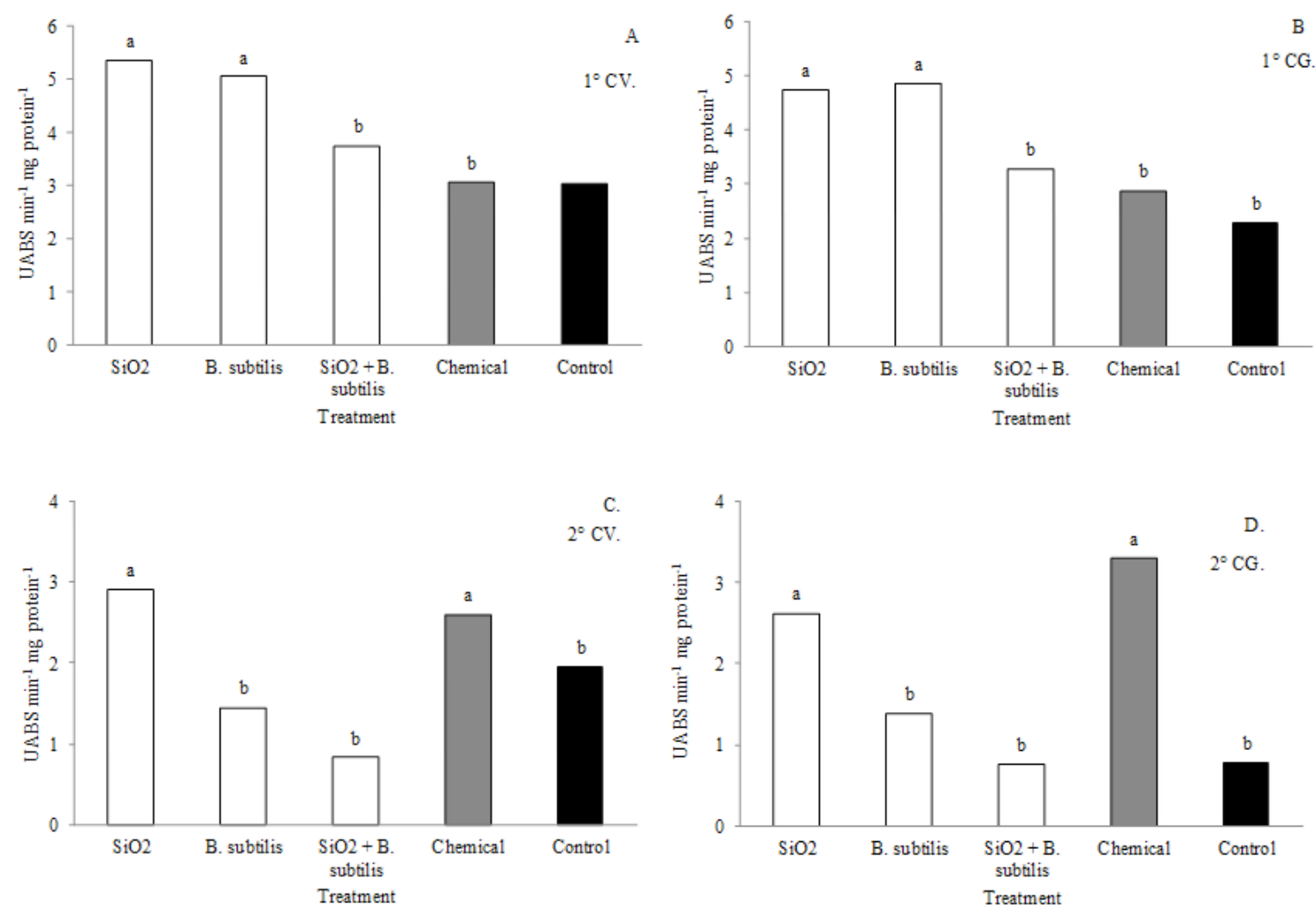

Figure 3. Specific activity of the enzyme phenylalanine ammonia-lyase(PAL) in wheat leaves treated with silicon dioxide $\left(\mathrm{SiO}_{2}\right)$; B. subtilis; $\mathrm{SiO}_{2}+B$. subtilis; trifloxystrobin + protioconazole/trifloxystronin + tebuconazole (chemical treatment) and Control (no application) on first and second collections in Virmond-PR (first VC (A) and second VC [C]) and Guarapuava-PR (first GC (B) and second GC (D) Means followed by the same letter on the line do not differ from each other by the Scott-Knott test $(p \geq 0.05)$.

interfered in the infectious process of these pathogens in leaves and ears, but did not contribute significantly to the agronomic characteristics of the crop.

However, fungicides also showed an increase in enzyme activity, as both fungicides have strobilurins in their composition, which in turn act directly on the pathogen, interfering with respiration and may have a positive effect on plant physiology, improving growth and metabolism, in addition to boosting the plant resistance to induction mechanisms of pathogens (Colombari et al., 2018).

\section{Conclusions}

Application of $\mathrm{SiO}_{2}$ does not affect the agronomic characteristics of wheat, but increases the activity of PPO and PAL enzymes, activating the defense mechanisms of wheat plants.

\section{Literature Cited}

Amorim, L.; Kuniyuki, H. Doenças da videira. In: Kimati, H.; Amorim, L.; Bergamin Filho, A.; Camargo, L.E.A., Rezende, J.A.M. (Eds.) Manual de fitopatologia: doenças das plantas cultivadas. 4.ed. São Paulo: Agronômica Ceres, 2011. v.2. p. 736-757.

Azevedo, L.A.S. Manual de quantificação de doenças de plantas. São Paulo: Luiz Antônio Siqueira de Azevedo, 1997. 114p.
Baig, U.; Gondal, M. A.; Ansari, M. A.; Akhtar, S. Facile synthesis, characterization and antibacterial activity of nanostructured palladium loaded silicon carbide. Ceramics International, v.44, n.14, p.1690816914, 2018. https://doi.org/10.1016/j.ceramint.2018.06.129.

Bakhat, H. F.; Bibi, N.; Zia, Z.; Abbas, S.; Hammad, H. M.; Fahad, S.; Ashraf, M. R.; Shah, G. M.; Rabbani, F.; Saeed, S. Silicon mitigates biotic stresses in crop plants: a review. Crop Protection, v.104, p.21-34, 2018. https://doi.org/10.1016/j.cropro.2017.10.008.

Bradford, M. M. A rapid and sensitive method for the quantitation of microgram quantities of protein utilizing the principle of proteindye binding. Analytical Biochemistry, v.72, n.1-2, p.248-254, 1976. https://doi.org/10.1016/0003-2697(76)90527-3.

Colombari, L. F.; Baldini, L. F. G.; Silva, F. Z. D.; Ono, E. O.; Rodrigues, J. D.; Goto, R. Controle químico da hérnia das crucíferas em rúcula cultivada em campo naturalmente infestado. Revista de Ciências Agrárias, v.41, n.4, p.231-240, 2018. https://doi.org/10.19084/RCA17178.

Comby, M.; Gacoin, M.; Robineau, M.; Rabenoelina, F.; Ptas, S., Dupont, J.; Profizi, C.; Baillieul, F. Screening of wheat endophytes as biological control agents against Fusarium head blight using two different in vitro tests. Microbiological research, v.202, p.1120, 2017. https://doi.org/10.1016/j.micres.2017.04.014.

Companhia Nacional de Abastecimento - Conab. Acompanhamento da safra brasileira de grãos: monitoramento agrícola safra 2017/2018. Brasília: Conab, 2018. v. 5, n. 9. 178p. https://www. conab.gov.br/info-agro/safras/graos/boletim-da-safra-de-graos/ item/download/20861_fb79e3ca2b3184543c580cd4a4aa402b. 15 Jan. 2019. 
Deuner, C. C.; Viana, E.; Camara, J. N.; Reis, E. M. Resistência de cultivares de trigo à giberela mediante inoculação artificial em espiguetas. Summa Phytopathologica, v.41, n.3, p.202-206, 2015. https://doi.org/10.1590/0100-5405/1994.

Dorneles, K. R.; Posso, D .A.; Rebhahn, I.; Deuner, S.; Pazdlora, P.C.; Avila, L. A.; Dallagnol, L. J. Respostas morfofisiológicas de grãos do trigo mediados pelo aumento da concentração de $\mathrm{CO}_{2}$ atmosférico. Revista Brasileira de Ciências Agrárias, v.14, n.1, p.17, 2019. https://doi.org/10.5039/agraria.v14i1a5600.

Duangmal, K.; Apenten, R. K. O. A comparative estudy of poliphenoloxidases from taro (Colocasia esculenta) and potato (Solanum tuberosum var. Romano). Food Chemistry, v. 64, n.3, p. 351-359, 1999. https://doi.org/10.1016/S0308-8146(98)00127-7.

Elsherbiny, E. A., Taher, M. A. Silicon induces resistance to postharvest rot of carrot caused by Sclerotinia sclerotiorum and the possible of defense mechanisms. Postharvest Biology and Technology, v.140, p.11-17, 2018. https://doi.org/10.1016/j.postharvbio.2018.02.004.

Fagan, E. B.; Neto, D. D.; Vivian, R.; Franco, R. B.; Yeda, M. P.; Massignam, L. F.; Martins, K. V. Efeito da aplicação de piraclostrobina na taxa fotossintética, respiração, atividade da enzima nitrato redutase e produtividade de grãos de soja. Bragantia, v.69, n.4, p.771-777, 2010. https://doi.org/10.1590/S0006-87052010000400001.

Ferreira, D. F. SISVAR: a computer statistical analysis system. Ciência e Agrotecnologia, v. 35, n.6, p.1039-1042, 2011. https://doi. org/10.1590/S1413-70542011000600001.

Fira, D.; Dimkić, I.; Berić, T.; Lozo, J.; Stanković, S. Biological control of plant pathogens by Bacillus species. Journal of Biotechnology, v.285, p. 44-55, 2018. https://doi.org/10.1016/j. jbiotec.2018.07.044.

Gutkoski, L. C.; Durigon, A.; Mazzutti, S.; Silva, A. C. T.; Elias, M. C. Efeito do período de maturação de grãos nas propriedades físicas e reológicas de trigo. Ciência e Tecnologia de Alimentos, v.28, n.4, p.888-894, 2008. https://doi.org/10.1590/S010120612008000400019.

Instituto Phytus. Fungicidas: modo de ação e programas de controle. Atualizações Phytus. 2015. https://www.agrolink.com.br/ agrolinkfito. 05 Jul. 2019.

Kanungo, M.; Joshi, J. Impact of pyraclostrobin (F-500) on crop plants. Plant Science Today, v. 1, n. 3, p. 174-178, 2014. https:// doi.org/10.14719/pst.2014.1.3.60.

Maillard, A.; Ali, N.; Schwarzenberg, A.; Jamois, F.; Yvin, J. C.; Hosseini, S. A. Silicon transcriptionally regulates sulfur and ABA metabolism and delays leaf senescence in barley under combined sulfur deficiency and osmotic stress. Environmental and Experimental Botany, v.155, p. 394-410, 2018. https://doi. org/10.1016/j.envexpbot.2018.07.026.
Matos, G. A.; Sousa, F. A.; Júnior, J. P.; Lima, L. M. Avaliação da mistura de fungicidas no controle de doenças do cafeeiro. Revista GeTeC, v. 5, n. 9, 2016. http://www.fucamp.edu.br/editora/index.php/ getec/article/view/756. 05 Jul. 2019.

Melero, M. M.; Gitti, D. C.; Arf, O.; Rodrigues, R. A. F. Coberturas vegetais e doses de nitrogênio em trigo sob sistema plantio direto. Pesquisa Agropecuária Tropical, v.43, n.4, p.343-353, 2013. https://doi.org/10.1590/S1983-40632013000400001.

Moffat, C. S.; See, P. T.; Oliver, R. P. Generation of a Tox A knockout strain of the wheat tan spot pathogen Pyrenophora triticirepentis. Molecular Plant Pathology, v.15, n.9, p.918-926, 2014. https://doi.org/10.1111/mpp.12154.

Oliveira, M. D. M.; Varanda, C. M. R.; Félix, M. R. F. Induced resistance during the interaction pathogen $x$ plant and the use of resistance inducers. Phytochemistry letters, v.15, p.152-158, 2016. https:// doi.org/10.1016/j.phytol.2015.12.011.

Prado, G. Contaminação de alimentos por micotoxinas no Brasil e no mundo. Gerais: Revista de Saúde Pública do SUS/MG, v.2, n.2, p.13-26, 2017. http://revistageraissaude.mg.gov.br/index.php/ gerais41/article/view/298. 08 Abr. 2019.

Prestes, A. M.; Santos, H.P. Dos; Reis, E. M. Práticas culturais e incidência de manchas foliares em trigo. Pesquisa Agropecuária Brasileira, v. 37, n. 6, p. 791-797, 2002. https://doi.org/10.1590/ S0100-204X2002000600008.

Reis, E. M.; Casa, R. T.; Medeiros, C. A. Diagnose, patometria e controle de doenças de cereais de inverno. Universidade de Passo Fundo, Faculdade de Agronomia e Medicina Veterinária, 2001. 94p.

Shalaby, S.; Benjamin, A. H. Plant phenolic compounds and oxidative stress: integrated signals in fungal-plant interactions. Current Genetics, v. 61, n. 3, p. 347-357, 2015. https://doi.org/10.1007/ s00294-014-0458-6.

Sistema Meteorológico do Paraná - Simepar. Clima 2016. Guarapuava, Virmond. http://www.simepar.br. 15 Jan. 2019.

Song, A.; Xue, G.; Cui, P.; Fan, F.; Liu, H.; Yin, C.; Wanchun, S.; Liang, $Y$. The role of silicon in enhancing resistance to bacterial blight of hydroponic-and soil-cultured rice. Scientific Reports, v.6, article 24640, 2016. https://doi.org/10.1038/srep24640.

Umesha, S. Phenylalanine ammonia-lyase activity in tomato seed lings and its relations chipto bacterial cankered sease resistence. Phytoparasitica, v. 34, n. 1, p. 68-71, 2006. https:// doi.org/10.1007/BF02981341.

Zhang, X.; Chang-Jun, L. Multifaceted regulations of gateway enzyme phenylalanine ammonia-lyase in the biosynthesis of phenylpropanoids. Molecular Plant, v. 8, n. 1, p. 17-27, 2015. https://doi.org/10.1016/j.molp.2014.11.001. 